\title{
Effect of Integrated Nutrient Management on Growth, Yield and Fruit Quality of Sweet Orange (Citrus sinensis L.) cv. Mosambi
}

\author{
Gaurav Kumar ${ }^{1}$, Nidhika Thakur ${ }^{1 *}$, Gagandeep Singh ${ }^{2}$ and Saurabh Tomar ${ }^{3}$ \\ ${ }^{1}$ Department of Fruit Science, VCSG, UUHF, Bharsar, Pauri Garhwal, U.K., India \\ ${ }^{2}$ Department of Entomology, Dr. YSPUHF, Nauni, Solan, H.P., India \\ ${ }^{3}$ Department of Fruit Science, CSA, University of Agriculture and Technology, \\ Kanpur, U.P., India \\ *Corresponding author
}

\section{A B S T R A C T}

\section{Keywords}

Integrated nutrient management, Sweet orange, Organic manure, Farmyard manure, Vermicompost.

Article Info Accepted: 26 June 2017 Available Online: 10 July 2017
A systematic study was undertaken to determine the best treatment of integrated nutrient management for the growth, yield and quality of sweet orange. The experiment was laid out in Randomized Complete Block Design with seven treatments and four replications viz., $\mathrm{T}_{1}$ : Control $(250 \mathrm{~g} \mathrm{~N}+180 \mathrm{~g} \mathrm{P}+150 \mathrm{~g} \mathrm{~K}+15 \mathrm{~kg} \mathrm{FYM}), \mathrm{T}_{2}: 75 \%$ nitrogen of recommended dose of fertilizer $+25 \%$ organic manure (vermicompost), $\mathrm{T}_{3}: 60 \%$ nitrogen of recommended dose of fertilizer $+40 \%$ organic manure (FYM), $\mathrm{T}_{4}: 60 \%$ nitrogen of recommended dose of fertilizer $+40 \%$ organic manure (vermicompost), $\mathrm{T}_{5}: 50 \%$ nitrogen of recommended dose of fertilizer $+50 \%$ organic manure (FYM), $\mathrm{T}_{6}: 50 \%$ nitrogen of recommended dose of fertilizer $+50 \%$ organic manure (vermicompost) and $\mathrm{T}_{7}$ : $75 \%$ nitrogen of recommended dose of fertilizer $+25 \%$ organic manure (FYM). Based on the results obtained from the present investigations, it was observed that the highest tree height, annual shoot growth, fruit set, fruit yield, fruit weight, fruit size, fruit volume and fruit quality characteristics like TSS, reducing sugar, total sugar and non-reducing sugar were observed with treatment $\mathrm{T}_{3}[60 \%$ nitrogen of recommended dose of fertilizer $+40 \%$ organic manure (FYM)].

\section{Introduction}

Sweet orange (Citrus sinensis L.) is an important fruit crop which belongs to family Rutaceae and is a native of China. Among the citrus fruits in India, sweet orange is the second most important fruit, occupying an area of 107 lakh hac with a production of $1117 \mathrm{MT}$ and a productivity of $16.7 \mathrm{MT} / \mathrm{hac}$, while in Uttarakhand citrus is grown in an area of 171 thousand hac with the production of $678 \mathrm{MT}$ and productivity of $10.3 \mathrm{MT} / \mathrm{hac}$. In India, it is majorly grown in Punjab, Himachal Pradesh, Uttarakhand, Rajasthan,
Andhra Pradesh and Marathwada region of Maharashtra. The common people of India generally suffer from different malnutrition problems, not only from the deficiency of proteins and calories, but also from the deficiency of different vitamins like vitamin $\mathrm{A}$ and vitamin $\mathrm{C}$ and minerals like calcium and iron. All such malnutrition problems could have been reduced considerably if the people of India would have adequate access of fruits, especially citrus fruits which are generally known to be rich in these vitamins 
and minerals. Citrus has also some medicinal value (Reuther et al., 1968). The production of fruits can be increased by proper supply of nutrients in the form of fertilizer. Fertilizer is one of the major inputs accounting for nearly one third of the cost of cultivation and its production consumes a lot of energy used in horticulture. The conventional farming system involves enormous use of chemical in horticultural production. Continuous use of chemical fertilizers has degraded the soil health in terms of fertility and has also caused soil pollution. Organic manures have been used for their eco-friendly and beneficial effect on environment and horticultural crops. The era of development in the field of integrated nutrient management will ensure fairly high level of fruit production with sufficiently reduced dose of fertilizers and nutrients. Therefore, increasing need is being felt to integrate nutrient supply with organic sources to restore the health of soil.

\section{Materials and Methods}

The studies were carried out at the citrus orchard of Department of Fruit Science, VCSG Uttarakhand University of Horticulture and Forestry, Bharsar, Pauri Garhwal during 2015-16. Three years old Mosambi trees having uniform size and vigour were selected. The experiment was laid out in Randomized Complete Block Design with seven treatments and four replications viz., $\mathrm{T}_{1}$ : Control $(250 \mathrm{~g}$ $\mathrm{N}+180 \mathrm{~g} \mathrm{P}+150 \mathrm{~g} \mathrm{~K}+15 \mathrm{~kg}$ FYM), $\mathrm{T}_{2}: 75 \%$ nitrogen of recommended dose of fertilizer + $25 \%$ organic manure (vermicompost), $\mathrm{T}_{3}$ : $60 \%$ nitrogen of recommended dose of fertilizer $+40 \%$ organic manure (FYM), $\mathrm{T}_{4}$ : $60 \%$ nitrogen of recommended dose of fertilizer $+40 \%$ organic manure (vermicompost), $\mathrm{T}_{5}: 50 \%$ nitrogen of recommended dose of fertilizer $+50 \%$ organic manure (FYM), $\mathrm{T}_{6}: 50 \%$ nitrogen of recommended dose of fertilizer $+50 \%$ organic manure (vermicompost) and $\mathrm{T}_{7}: 75 \%$ nitrogen of recommended dose of fertilizer +
$25 \%$ organic manure (FYM). The required quantity of inorganic fertilizers, (full dose of $\mathrm{P}_{2} \mathrm{O}_{5}$ and $\mathrm{K}_{2} \mathrm{O}$ ) were applied during January along with FYM and vermicompost by broadcasting under the spread of trees, $30 \mathrm{~cm}$ away from the trunk and were mixed with the soil. The nitrogen was applied in split doses, half during spring before flowering and remaining half dose was applied one month after first application.

\section{Results and Discussion}

\section{Growth characteristics}

The integrated nutrient management affected vegetative growth (Table 1). The maximum tree height increment (11.6 inch) and annual shoot growth $(34.93 \mathrm{~cm})$ were recorded with treatment $\mathrm{T}_{3}[60 \%$ nitrogen of recommended dose of fertilizer $+40 \%$ organic manure (FYM)]. This might be due to improved nutritional status and physical properties of the soil caused by the addition of FYM. This made the plant to uptake water and mineral nutrients better, resulting in its increased growth rate. Similarly, significant growth of kinnow mandarin by the application of FYM has been earlier reported by Dudi et al., (2003). The data on the effect of nitrogen revealed that the application of organic and inorganic fertilizer increased the plant height, tree volume and trunk growth. Application of nitrogen resulted in vigorous vegetative growth of the plant and gave dark green colour of the foliage. This favoured the photosynthetic activity of the plants and greater synthesis of carbohydrate, which led to the formation of amino acids, nucleoproteins, chlorophyll, alkaloids and amides. These complex compounds were responsible for building up of new tissues and were associated with a number of metabolic processes, which in turn favoured better development of plants. The increase in growth as a result of nitrogen application is obvious. Similarly, increase in vegetative growth of 
fruit plants by the application of nitrogen has also been reported earlier by Kaul and Bhatnagar (2006) in Kinnow mandarin.

\section{Fruit set and fruit yield ( $\mathrm{kg} /$ tree $)$}

The integrated nutrient management influenced the fruit set and fruit yield. The highest fruit set $(70.28 \%)$ and fruit yield $(2.68 \mathrm{~kg} / \mathrm{tree})$ were observed with the treatment $\mathrm{T}_{3}[60 \%$ nitrogen of recommended dose of fertilizer $+40 \%$ organic manure (FYM)]. Increase in fruit set and fruit yield with $60 \%$ NPK fertilizer doses in association with $40 \%$ nutrients through farm yard manure was due to the optimum supply of plant nutrients and growth hormones at desired amount during entire period of fruit growth, ultimately resulting in accumulation of more photosynthates leading to more fruit development and yield of fruits.

The increase in both fruit number and fruit weight might be attributed to the fact that, there was increase in level of nutrients in assimilating area of crop due to which the rate of dry matter production was enhanced. Similarly, due to rational partitioning of dry matter to economic sink, the yield attributes were improved. The above results are in conformity with the findings of Dalal et al., (2004).

Fruit set and fruit yield are highly correlated with dry matter content and balanced level of hormones. Superior fruit quality might be due to the fact that, farm yard manure combined with fertilizers enhanced the nutrient availability by enhancing the capability of plants to better solute uptake from rhizosphere. The findings are in accordance with Gawande et al., (1998) and Patel and Naik (2010) in lemon.

Table.1 Effect of integrated nutrient management on tree height increment and Annual branch growth of sweet orange cv. Mosambi

\begin{tabular}{|c|c|c|c|c|}
\hline Treatments & $\begin{array}{c}\text { Tree height } \\
\text { increment (inch) }\end{array}$ & $\begin{array}{l}\text { Annual shoot } \\
\text { growth }(\mathbf{c m})\end{array}$ & $\begin{array}{c}\text { Fruit } \\
\text { set }(\%)\end{array}$ & $\begin{array}{c}\text { Fruit yield } \\
\text { (kg/tree) }\end{array}$ \\
\hline$T_{1}$ (Control)- $250 \mathrm{~g} \mathrm{~N}+150 \mathrm{~g} \mathrm{P}+180 \mathrm{~g} \mathrm{~K}+15 \mathrm{~kg}$ FYM & 5.18 & 21.12 & 54.58 & 1.58 \\
\hline $\mathrm{T}_{2} 75 \% \mathrm{~N}$ of $\mathrm{RDF}+25 \% \mathrm{OM}(\mathrm{VC})$ & 9.33 & 28.48 & 48.00 & 2.22 \\
\hline$T_{3} 60 \% \mathrm{~N}$ of RDF $+40 \%$ OM (FYM) & 11.63 & 34.93 & 70.28 & 2.68 \\
\hline $\mathrm{T}_{4} 60 \% \mathrm{~N}$ of RDF $+40 \% \mathrm{OM}(\mathrm{VC})$ & 8.75 & 27.32 & 63.64 & 1.87 \\
\hline$T_{5} 50 \% \mathrm{~N}$ of RDF + $50 \%$ OM (FYM) & 8.03 & 25.26 & 63.45 & 1.50 \\
\hline $\mathrm{T}_{6} 50 \% \mathrm{~N}$ of RDF $+50 \%$ OM (VC) & 9.30 & 22.68 & 49.96 & 1.36 \\
\hline $\mathrm{T}_{7} 75 \% \mathrm{~N}$ of RDF $+25 \%$ OM (FYM) & 9.98 & 25.20 & 48.93 & 2.10 \\
\hline SE (d) & 0.81 & 0.51 & 7.59 & 0.20 \\
\hline $\mathbf{C D}_{(0.05)}$ & 1.71 & 1.07 & 1.50 & 0.43 \\
\hline
\end{tabular}

N- Nitrogen, RDF- Recommended Dose of Fertilizer, OM- Organic Manure, FYM- Farm Yard Manure, VCVermicompost

Table.2 Effect of integrated nutrient management on fruit weight, fruit size and Fruit volume of sweet orange cv. Mosambi

\begin{tabular}{|c|c|c|c|c|}
\hline Treatments & $\begin{array}{c}\text { Fruit } \\
\text { weight }(\mathrm{g})\end{array}$ & $\begin{array}{c}\text { Fruit length } \\
(\mathbf{c m})\end{array}$ & $\begin{array}{c}\text { Fruit breadth } \\
(\mathrm{cm})\end{array}$ & $\begin{array}{c}\text { Fruit volume } \\
\left(\mathrm{cm}^{3}\right)\end{array}$ \\
\hline$T_{1}$ (Control)- $250 \mathrm{~g} \mathrm{~N}+150 \mathrm{~g} \mathrm{P}+180 \mathrm{~g} \mathrm{~N}$ of RDF $+15 \mathrm{~kg} \mathrm{FYM}$ & 93.77 & 5.15 & 5.05 & 137.53 \\
\hline $\mathrm{T}_{2} 75 \% \mathrm{~N}$ of RDF $+25 \% \mathrm{OM}(\mathrm{VC})$ & 141.36 & 5.43 & 5.45 & 170.65 \\
\hline $\mathrm{T}_{3} 60 \% \mathrm{~N}$ of RDF $+40 \%$ OM (FYM) & 152.81 & 6.33 & 6.15 & 250.67 \\
\hline $\mathrm{T}_{4} 60 \% \mathrm{~N}$ of RDF $+40 \% \mathrm{OM}(\mathrm{VC})$ & 98.59 & 5.28 & 5.15 & 146.77 \\
\hline$T_{5} 50 \% \mathrm{~N}$ of RDF $+50 \%$ OM $(\mathrm{FYM})$ & 119.01 & 5.63 & 5.65 & 188.16 \\
\hline $\mathrm{T}_{6} 50 \% \mathrm{~N}$ of RDF $+50 \% \mathrm{OM}(\mathrm{VC})$ & 100.31 & 5.45 & 5.58 & 178.02 \\
\hline $\mathrm{T}_{7} 75 \% \mathrm{~N}$ of RDF $+25 \%$ OM (FYM) & 124.00 & 6.10 & 5.48 & 192.18 \\
\hline SE (d) & 7.40 & 0.13 & 0.14 & 10.75 \\
\hline $\mathbf{C D}_{(0.05)}$ & 15.66 & 0.28 & 0.30 & 22.77 \\
\hline
\end{tabular}

N- Nitrogen, RDF- Recommended Dose of Fertilizer, OM- Organic Manure, FYM- Farm Yard Manure, VC

Vermicompost 
Table.3 Effect of integrated nutrient management on total soluble solids, reducing sugar, Non-reducing sugar and total sugar of sweet orange cv. Mosambi

\begin{tabular}{|c|c|c|c|c|}
\hline Treatments & $\begin{array}{c}\text { TSS } \\
\left({ }^{\circ} \text { Brix }\right)\end{array}$ & $\begin{array}{c}\text { Reducing sugars } \\
(\%)\end{array}$ & $\begin{array}{c}\text { Non-reducing } \\
\text { sugars }(\%)\end{array}$ & $\begin{array}{c}\text { Total sugars } \\
(\%)\end{array}$ \\
\hline$T_{1}$ Control- $250 \mathrm{~g} \mathrm{~N}+150 \mathrm{~g} P+180 \mathrm{~g} N$ of RDF + $15 \mathrm{~kg}$ FYM & 8.33 & 3.00 & 3.11 & 6.11 \\
\hline$T_{2} 75 \% \mathrm{~N}$ of RDF $+25 \% \mathrm{OM}(\mathrm{VC})$ & 9.33 & 3.12 & 3.18 & 6.30 \\
\hline $\mathrm{T}_{3} 60 \% \mathrm{~N}$ of RDF $+40 \%$ OM (FYM) & 10.58 & 3.17 & 3.54 & 6.70 \\
\hline $\mathrm{T}_{4} 60 \% \mathrm{~N}$ of RDF $+40 \% \mathrm{OM}(\mathrm{VC})$ & 10.38 & 2.92 & 3.03 & 5.95 \\
\hline $\mathrm{T}_{5} 50 \% \mathrm{~N}$ of RDF $+50 \%$ OM (FYM) & 9.30 & 2.97 & 3.00 & 5.97 \\
\hline $\mathrm{T}_{6} 50 \% \mathrm{~N}$ of RDF + $50 \% \mathrm{OM}(\mathrm{VC})$ & 8.23 & 2.83 & 2.99 & 5.83 \\
\hline $\mathrm{T}_{7} 75 \% \mathrm{~N}$ of RDF $+25 \%$ OM (FYM) & 8.38 & 2.99 & 3.12 & 6.11 \\
\hline SE (d) & 0.09 & 0.05 & 0.04 & 0.08 \\
\hline $\mathbf{C D}_{(0.05)}$ & 0.19 & 0.11 & 0.09 & 0.16 \\
\hline
\end{tabular}

N- Nitrogen, RDF- Recommended Dose of Fertilizer, OM- Organic Manure, FYM- Farm Yard Manure, VC Vermicompost

\section{Fruit quality characteristics}

The quality parameters (Table 2 and 3) of fruits were markedly improved by integrated application of inorganic fertilizers and organic manures. The maximum fruit weight $(152.81$ $\mathrm{g})$, fruit length $(6.33 \mathrm{~cm})$, fruit breadth $(6.15$ $\mathrm{cm})$, fruit volume $\left(250.67 \mathrm{~cm}^{3}\right)$, total soluble solids $\left(10.58{ }^{\circ} \mathrm{B}\right)$, total sugars $(6.70 \%)$, reducing sugars $(3.17 \%)$, non-reducing sugars $(3.54 \%)$ were recorded with the application of $\mathrm{T}_{3} \quad[60 \%$ nitrogen of recommended dose of fertilizer $+40 \%$ organic manure (FYM)]. This might be due to good nutrient status, improved plant conditions, efficient functioning of leaf area and increased photosynthetic activity. These results are in conformity with the results obtained by Singh and Banik (2011) in sweet orange. It was further observed that significant increase in TSS was recorded by the application of FYM and NPK. This was because adequate dose of NPK stimulated the functioning of number of enzymes in the physiological process which might have increased the total soluble solid content of the fruits.

The sugars (total sugar, reducing sugar and non-reducing sugar) increased significantly by the application of NPK. The highest mean values for sugars with the application of NPK could be attributed to the involvement of nitrogen in various energy sources like amino acids and amino sugars. Over dose of NPK decreases the TSS, ascorbic acid and sugars (total sugar, reducing sugar and non-reducing sugar). This was because when it reached the toxicity level, it decreased other enzymes and nutrient molecules which helped in the synthesis of these quality attributes. These results are in conformity with the results obtained by Prasad and Mali (2000) in lemon, Kaul and Bhatanagar (2006) in kinnow and Kashyap et al., (2012) in mandrin. Similar findings were earlier reported by Sharma et al., (2013).

Nitrogen leads to increased average fruit weight, fruit length, fruit diameter and fruit volume of kinnow fruits. This is due to the fact that nitrogen increased the efficiency of metabolic process of the plants and thus encouraged the growth of the plant and consequently increased the size and weight of the fruit.

Another probable cause could be greater mobility of nutrients to the developing fruits which act as strong metabolic sink (Dudi et al., 2004). The reduction in juice content caused by high doses of nitrogen might be due to the thickness of the peel. Carranca et al., (1992) reported that the production of sweet oranges and mandarins flower and fruit were high by the application of the highest level of nitrogen but the total yield was maximum by the application of medium level 
of nitrogen. These results are in accordance with the findings of Hiwale et al., (2010) in citrus.

Based on the results obtained from the present investigations, it was observed that the highest tree height, annual branch growth, fruit set, fruit yield, fruit weight, fruit size and fruit volume and fruit quality characteristics like TSS, reducing sugar, total sugar and nonreducing sugar were observed with treatment $\mathrm{T}_{3}[60 \%$ nitrogen of recommended dose of fertilizer $+40 \%$ organic manure (FYM)]. Hence, it is concluded that the integrated use of organic and inorganic source of nutrients in treatment $\mathrm{T}_{3}[60 \%$ nitrogen of recommended dose of fertilizer $+40 \%$ organic manure (FYM)] was found most effective in improving the growth, yield and quality of sweet orange fruits.

\section{References}

Carranca C F, Baeta J and Fragaso M C. 1992. Effect of $\mathrm{N} \mathrm{P}$ and $\mathrm{K}$ fertilization on leaf nutrient content and fruit quality of Valencia Late orange trees. In: Optimization of Plant Nutrition 20: 27-32.

Dalal S R, Gonge V S Jogdande N D and Moharia A. 2004. Response of different levels of nutrients and PSB on fruit yield and economics of citrus. PKV Research Journal 28:126-128.

Dudi O P, Kumar S, Singh S and Singh D. 2004. Effect of urea and FYM on fruit size and yield of Kinnow mandarin. Haryana Journal of Horticulture Science 33(3-4): 179-180.

Dudi O P, Singh D, Dahiya S S and Bhatia S K. 2003. Impact of various levels of N and FYM on growth parameters of kinnow mandarin. Haryana Jouranl of Horticulture Science
32(1-2): 29-31.

Gawande S S, Jitonde D J, Turkhede A B and Darange S O. 1998. Effect of organic and inorganic fertilizers on yield and quality of lemon. Journal of Soils Crops 8(1): 58-60.

Hiwale S S, Apparao V V, Dhandhar D G and Bagle B G. 2010. Effect of nutrient replenishment through organic fertilizers in citrus. Indian Journal of Horticulture 67(2): 274-276.

Kashyap P, Pramanick K K, Meena K K and Meena V. 2012. Effect of $\mathrm{N}$ and $\mathrm{P}$ application on yield and quality of mandarin (Citrus reticulata). Indian Journal of Horticulture 69(3): 322-327.

Kaul M K and Bhatnagar P. 2006. Nutritional studies in kinnow. Indian Journal of Arid Horticulture 1(1): 23-24.

Patel D R and Naik A G. 2010. Effect of pre harvest treatments of organic manures and inorganic fertilizers on post-harvest shelf life of lemon. Indian Journal Horticulture 67(3): 381-386.

Prasad R N and Mali P C. 2000. Effect of different levels of nitrogen on quality characters of lemon. Haryana Journal of Horticulture Science 29(3-4): 186-187.

Sharma A, Wali V K, Bakshi P and Jastora A. 2013. Effect of organic and inorganic fertilizers on quality and shelf life of lemon. The Bioscan 8(4): 1247-1250.

Sharma K L and Chopra S K. 2000. Effect of nitrogen, phosphorus and potash on the growth and yield of Blood Red sweet orange (Citrus sinensis Osbeck) if grown in foot hills and valley areas of Himachal Pradesh. Punjab Horticulutre Journal 40:19-23.

Singh S R and Banik B C. 2011. Response of integrated nutrient management on flowering, fruit setting, yield and fruit quality in sweet orange (Citrus sinensis). Asian Journal of Horticulture 6(1): 151- 154.

\section{How to cite this article:}

Gaurav Kumar, Nidhika Thakur, Gagandeep Singh and Saurabh Tomar. 2017. Effect of Integrated Nutrient Management on Growth, Yield and Fruit Quality of Sweet Orange (Citrus sinensis L.) cv. Mosambi. Int.J.Curr.Microbiol.App.Sci. 6(7): 2333-2337.

doi: https://doi.org/10.20546/ijcmas.2017.607.333 